\title{
Corporate Social Responsibility (CSR) Disclosure of Indonesian Islamic Bank
}

\author{
Naelati Tubastuvi ${ }^{1}$, Azmi Fitriati ${ }^{2}$, Diska Tristiandini ${ }^{3}$, Sobrotul Imtikhanah ${ }^{4}$ \\ \{naelatitubastuvi@ump.ac.id ${ }^{1}$ \}
}

Faculty of Economics and Business, Universitas Muhammadiyah Purwokerto ${ }^{123}$, Faculty of Economics and Business, Universitas Muhammadiyah Pekajangan Pekalongan ${ }^{4}$

\begin{abstract}
The purpose of this study is analysing the influence of profitability, company size, leverage, and sharia supervisory board size on corporate social responsibility disclosure (CSR). The population study is Indonesian Islamic banks in the periods 2014-2018. This research study used a purposive sampling method as sample method. The number of samples is 14 Islamic banks. Data were analyzed by descriptive statistics, classical assumption tests, and multiple regression analysis. The results showed that company size has a positive influence, and leverage has a negative influence on CSR disclosure. Profitability and sharia supervisory board size did not influence CSR disclosure.
\end{abstract}

Keywords: Corporate Social Responsibility Disclosure (CSR), Profitability, Company Size, Leverage, S Haria Supervisory B cards Size.

\section{Introduction}

The global Islamic finance industry continues to experience development from year to year. In 2016, the global Islamic finance industry's total assets reached the US \$ 2.202 billion, increasing from the previous year's US $\$ 2.063$ billion. The projection of the Islamic financial industry in the future has a combined growth potential of $9.4 \%$ with the assumption of a financial potential of US $\$ 3.782$ billion in 2022 . This potential growth is influenced by an increase in the world's Muslim population, an increase in the per capita income of the Muslim population and awareness of Islamic finance. [1]

The sizeable potential growth for global Islamic finance has impacted the development of Islamic finance in Indonesia, which is significant and can continue to develop in the future. As a country with the largest Muslim population, Indonesia is a substantial market for Islamic financial products. The growth of Islamic finance in Indonesia is quite significant. In 2017, Islamic banking grew to reach $26.97 \%$. The development of Islamic banking can be seen from amount of the growth Sharia Commercial Banks (BUS), Sharia Business Units (UUS), and Sharia Rural Banks (BPRS) with an increasing number. Islamic banking statistics from the Indonesian Financial Services Authority (FSA) at the end of 2017 show that there are 13 BUS, 21 UUS, and 167 BPRS. [2].

Despite significant growth, the market share of Indonesian Islamic banking is still meager, around $5.78 \%$ of total national banking assets. This fact indicates that the growth of Islamic finance is not comparable to the growth of conventional financial assets, it should be that the age of the Islamic finance industry has passed 15 years of Islamic finance market 
share can be above the current figure. Internationally, Indonesia is the ten most significant countries in Islamic finance, together with Saudi Arabia, Iran,the United Arab Emirates, Malaysia, Kuwait, Qatar, Banglades, Bahrain, and Turkey. However, Indonesia's contribution is only $4.11 \%$ of the country's total Islamic financial assets. -countries [3].

Islamic banking in Indonesia is required to continue to improve its business performance in facing challenges, both international competition and increasing the market share of domestic banking. A strategy is needed to increase the number of customers both in quantity and quality. One of the efforts to convince the public to make transactions at Islamic banks is to report Corporate Social Responsibility (CSR). Environmental harmony is a demand for today's industrial paradigm that every business actor must carry out. Every business actor must be responsible and manage environmental conditions optimally because the company's responsibility is not only related to the economic and social sectors but also must cover the environmental sector. Reporting and disclosure of accountability information by companies are included in a Corporate Social Responsibility (CSR) report. The concept of implementing Corporate Social Responsibility (CSR) was first put forward by Bowen (1953), explaining that this reporting concept is based on the social needs of the company environment. The social responsibility report aims to require companies to create environmental harmony and community welfare so that more open disclosures are needed in the environmental sector [4].

The implementation of social responsibility will bring benefits to the company. Image (image) and trust in the company will increase. Investors will also consider this to be one reason to invest. This definition implies that a company with Limited Liability Company (PT) form has a social responsibility towards the local community and the community in general [5]. The level of increase in CSR disclosure in Islamic commercial banks in Indonesia is still low, based on the Global Reporting Initiative (GRI) Index of 79 items from 2013 to 2014. The increase of CSR disclosure is $25 \%$, from 2014 to 2015 . It has increased by $30 \%$, and from 2015 to 2016 is stable at the percentage of 30\% (Annual Report, 2013-2016). his data explains that the lack of attention of sharia-banking business people in disclosing CSR, while the public will be more interested in conducting transactions if there is CSR disclosure in banks. It can improve the image of the banking sector.

Accordingly, it is important to study the factors that influence Corporate Social Responsibility (CSR). These factors can be optimized to encourage increased implementation of social responsibility of Indonesian Islamic Bank, some of these factors based on the study results include Profitability, Company Size, Leverage, and the Sharia Supervisory Board (DPS).

\section{Literature Review}

\subsection{CSR Approaches and Strategies}

Achieving the company's goals and strategies necessary to approach CSR can be done with a few $t$ through Home Visits by :

a) Legitimacy Theory

Legitimacy Theory difined as the social contract between the company and the community, where legitimate the company operates and uses economic resources. Company activities can have a positive or negative impact on society or the environment. Social disclosure is used to avoid social and environmental conflicts. 
The use of legitimacy theory in this study is related to Islamic banking's compliance with Islamic principles. This form of compliance is to carry out CSR disclosure in its annual reports that aim for getting good value and legitimacy from the community so that Islamic banking can continue to survive, [6].

b) Stakeholder Theory

[6] Ghazali and Chariri (2007; 409), Stakeholder Theory told that a company is not an entity that only aims to generate profits, but must provide benefits to all its stakeholders (shareholders, creditors, consumers, suppliers, government, society, analysts and other parties).

Factors influence company activity from outside and from within the company, and both can be referred to as Stakeholders. To get support from stakeholders, this is done by disclosing $\mathrm{CSR}$ in the annual report. Social disclosure is part of the company's communication with interests.

Furthermore, several CSR strategies are activities not limited to giving donations or donations without a continuing influence which will also have an impact on the economic and social environment in the long term so that CSR needs to be processed in such a way as to become a strategy for companies, which are not, of course, beneficial for the company at a time for the community and government [7].

\subsection{Previous Research}

Profitability has an essential meaning to maintain the viability of the company in the long run because profitability shows whether the entity has good prospects in the future or not. Companies with big profits will receive high pressure from stakeholders because they are required to be accountable for their companies' performance so that they comply with applicable regulations and do not interfere with the lives of the surrounding communities [8]. Research that has been conducted regarding the Profitability variable on Corporate Social Responsibility (CSR) disclousure, including by [8], with the results of the study of the Profitability variable, has a significant positive influence on Corporate Social Responsibility (CSR) disclousure. Similar to [4] research, the profitability variable results have a significant positive influence on Corporate Social Responsibility (CSR) disclousure. This opinion is the same as the results of research by [9], Nita (2015), and Arif (2015), which state that the Profitability variable has a significant positive influence on Corporate Social Responsibility (CSR) disclousure. In contrast to research from [10], [11], [12], [13], [14], [15], [16], and [17] which shows that profitability does not influence Corporate Social Responsibility (CSR) disclousure.

The bigger the size of a company, the more attention it gets from the market and the public [9]. Then research on Company Size on CSR disclosure. According to research by [8], company size has a significant positive influence on Corporate Social Responsibility (CSR) disclousure. This opinion is the same as research by [4], Suskim and Hafidz (2015), [12], [13], Abdul (2017), and [16] which state that company size has a significant positive influence. On Corporate Social Responsibility (CSR) disclousure. In contrast to the research results of [6], Yurmi et al. (2017), Nurfianto and Hanny (2015), Nita (2015), and [17] which show that company size does not influence Corporate Social Responsibility (CSR) disclousure. ).

Leverage, according to [18], is "the ability of a company to use assets or funds that have fixed costs ( fixed cost assets or finds) to increase the level of income ( return) for company owners." Furthermore, research on the influence of leverage on Corporate Social Responsibility (CSR) disclousure. According to [8], leverage has a significant positive 
influence on Corporate Social Responsibility (CSR) disclousure. This research is supported by research from Eni Puji (2017), Savina (2017), and Aulia (2015), which states that leverage has a significant positive influence on Corporate Social Responsibility (CSR) disclousure. In contrast to the results of research from [6], [10], [13], [16] which show that leverage does not influence Corporate Social Responsibility (CSR) disclousure.

The Sharia Supervisory Board (DPS) is a function in a sharia bank organization that is internally a sharia supervisory body and externally can maintain and increase public trust [14]. The results of further research are regarding the Sharia Supervisory Board's influence on Corporate Social Responsibility (CSR) disclousure. According to Wardatul (2016), the Sharia Supervisory Board has a significant positive influence on Corporate Social Responsibility (CSR) disclousure. Similar to the results of research from [14] which states that the Sharia Supervisory Board has a significant positive influence on Corporate Social Responsibility (CSR) disclousure. It differs from the results of research by [6], which show that the Sharia Supervisory Board does not influence Corporate Social Responsibility (CSR) disclousure.

\subsection{Hypothesis}

Based on literature review, 4 hypotheses were developed as follows:

Hypothesis 1: Profitability has a positive influence on CSR Disclosure

Hypothesis 2: Company Size has a positive influence on CSR Disclosure

Hypothesis 3: Leverage has a positive influence on CSR Disclosure

Hypothesis 4: Sharia Advisory Board (DPS) has a positive influence on CSR Disclosure

\section{Method}

The study used multiple linear regression for analysing. In this study, a regression test was carried out with the independent variable ( X ) on the dependent variable ( $Y$ ) [19].

The quantitative approach focuses on symptoms that have specific characteristics in human life, called variables [20].

\subsection{Population and sample}

The study used population of the whole Bank General Sharia (BUS) in Indonesia, which is registered in the FSA from the year 2014 to 2018. The sampling method used was purposive sampling. The determination of sample is taken based on the criteria formulating in advance, namely:

a. Indonesian Sharia Commercial Bank registered official at Financial Services Authority (OJK).

b. Islamic Banks who publishes an annual report of the year $2014-2018$.

\subsection{Method of collecting data}

The secondary data that uses in this research obtained from records, books, and magazines in the form of corporate publications, financial reports, government reports, articles, books, etc. The data obtained from secondary data does not need to be processed anymore [20]. 
Secondary data of the research were obtained from the financial reports of Islamic Commercial Banks (BUS) which are official registered with the Indonesian Financial Services Authority by accessing online published of financial reports from website www.ojk.co.id,

\subsection{Variable el research}

\section{a) Independent Variable}

1) Profitability (X1)

Profitability is the ratio that measure the influenceiveness of management, purpose to measure the size of the level of profits obtained sales or investment. The better the profitability ratio, the better it is to describe the company's high profitability [21].

The formula for calculating profitability [21] is as follows:

$$
\mathrm{ROA}=
$$

\section{2) Company Size (X2)}

Company size as independent variable used to explain the social disclosures that companies make in their annual reports. Usually, large companies will disclose more information be compare small companies [13].

The company's size is seen from the company's total assets, which can be used for the company's operational activities. If the company has higher total assets, the management will be more flexible in using assets in the company [16]. The total value of the company's assets can be obtained from the company's annual report.

In this study, company size is expressed by the total assets of companies listed on the IDX in millions of rupiah [16].

$$
\text { Size }=(\text { Total Asset })
$$

\section{3) Leverage (X3)}

Leverage company is the ability to maximize assets or fixed costs to maximize the company's return or income level. [18]. The formula for calculating leverage itself uses [22].

\section{4) Sharia Supervisory Board (X 4 )}

The sharia supervisory board referred to in this study is the amount of members of the sharia supervisory board. This measurement uses the amount of members of the sharia supervisory board, which refers to the research of Makoginta et al. (2017).

\section{b) Dependent Variable}

Corporate Social Responsibility (CSR) (Y)

Corporate Social Responsibility is described as a collection of practices, company policies in the form of programs incorporated into company business practices that aim to have a positive impact on society. [8]. To calculate Corporate Social Responsibility (CSR), [8].

Information:

CSRDIij $=$ Corporate Social Responsibility Disclosure Index at Companies J

$\mathrm{Xij} \quad=$ Dummy Variable: $1=$ If the item is disclosed; $0=$ If an item is not disclosed 
Using the multiple linear regression analysis method, this study regulates the relationship of two or more variables, also shows the direction of the relationship between assumed random/stochastic, which means it has a probabilistic distribution [19]. In this study, a regression test was carried out with the independent variable $(\mathrm{x})$ on the dependent variable $(\mathrm{y})$. Then the multiple linear regression equation used is:

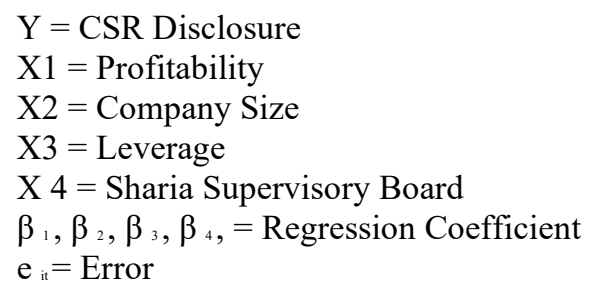

\section{Result and Discussion}

\section{1) Descriptive Statistics}

Descriptive statistics give an overview of data seen from the average value, standard deviation, variant, maximum, minimum, sum, range, kurtosis, and skewness (slope of distribution). To provide an overview of descriptive statistical analysis. [19].

\begin{tabular}{|c|c|c|c|c|c|}
\hline \multicolumn{6}{|c|}{ Descriptive Statistics } \\
\hline & $\mathrm{N}$ & Minimum & Maximum & Mean & Std. Deviation \\
\hline $\mathrm{X} 1 \_\mathrm{ROA}$ & 58 &,- 17 &, 08 &,- 0016 &, 03955 \\
\hline X2 SIZE & 58 & 27.22 & 32.22 & 29,9697 & 1,21477 \\
\hline X3_DER & 58 &, 25 & 5.96 & 1,4886 & 1.08312 \\
\hline X4 UDPS & 58 & 2.00 & 3.00 & 2,3103 & 46668 \\
\hline $\mathrm{Y} \quad \mathrm{CSR}$ & 58 &, 33 &, 56 &, 4628 &, 05712 \\
\hline $\begin{array}{ll}\text { Valid } & \mathrm{N} \\
\text { (listwise) } & \end{array}$ & 58 & & & & \\
\hline
\end{tabular}

Based on the descriptive statistics table, the profitability variable has a minimum value of 0.17 , a maximum value of 0.08 , an average ( mean ) of -0.0016 with a standard deviation of 0.3955 . The variable-sized companies have a minimum value: 27.22 , maximum value: 32.22 , Average value: 29.9697, and the standard deviation is 1, 21 477. Then for the leverage variable, it has a minimum value of 0.25 , a maximum value of 5.96 , an average ( 
mean ) of 1.4886 , with a standard deviation of 1.08312. Furthermore, to the variable, DPS has a minimum value of 2.00 , the maximum value of 3.00 , the average ( mean) by 2, 3103 with a standard deviation of 0.05712 .

\section{2) The regression equation}

The multiple linier regression analysis method measures the relationship all research variable, also shows the direction of the relationship between assumed random/stochastic, which means it has a probabilistic distribution [19]. In this study, a regression test was carried out with the independent variable $(\mathrm{x})$ on the dependent variable $(\mathrm{y})$. Then the multiple linear regression equation is used:

\section{3) Classical Assumption Test}

\section{a) Normality test}

The Kolmogorov Smirnov test that used in this research is a test with a two-tailed p-value (two-tailed), the criteria used is if the results of the KS calculation are more than 0.05 , that value concludes that there are normally distributed data [23].

\begin{tabular}{|c|c|c|}
\hline \multicolumn{3}{|c|}{ One-Sample Kolmogorov-Smirnov Test } \\
\hline & & Unstandardized Residual \\
\hline \multicolumn{2}{|l|}{$\mathrm{N}$} & 61 \\
\hline \multirow{2}{*}{${ }_{\mathrm{b}}$ Normal Parameters ${ }^{\mathrm{a}}$} & Mean &, 0000000 \\
\hline & Std. Deviation & 03651906 \\
\hline \multirow{3}{*}{$\begin{array}{l}\text { Most Extreme } \\
\text { Differences }\end{array}$} & Absolute &, 087 \\
\hline & Positive &, 050 \\
\hline & Negative &,- 087 \\
\hline \multicolumn{2}{|l|}{ Statistical Test } &, 087 \\
\hline \multicolumn{2}{|l|}{ Asymp. Sig. (2-tailed) } &, $200^{\mathrm{c}, \mathrm{d}}$ \\
\hline
\end{tabular}

In the Kolmogorov-Smirnov test, an asymp.sig value of 0.200 was obtained; this value fulfills the sig requirements. $(p)>0.05$. This means that the residual data is normally distributed.

\section{b) Multicollinearity Test}

Multicolonierity can be seen from the tolerance value and variance inflation factor (VIF). Which independent variable is described by the other independent variable will be indicated by the two measures. Tolerance is used to measure the variability of the selected independent variable not explained by other independent variables. A low tolerance value is the same as a high VIF value (because of VIF $=1 /$ Tolerance ).

\begin{tabular}{|l|l|l|l|l|l|l|}
\hline Coefficients a & \multicolumn{2}{|l|}{} \\
\hline Model & $\begin{array}{l}\text { Unstandardized } \\
\text { Coefficients }\end{array}$ & $\begin{array}{l}\text { Standardized } \\
\text { Coefficients }\end{array}$ & $\mathrm{t}$ & Sig. & \multicolumn{2}{|c|}{ Collinearity Statistics } \\
\cline { 2 - 4 } & $\mathrm{B}$ & Std. Error & Beta & & Tolerance & VIP \\
\hline
\end{tabular}




\begin{tabular}{|l|l|l|l|l|l|l|l|l|}
\hline 1 & (Constant) &,- &, 148 & & $-4,613$ &, & & \\
\cline { 2 - 9 } & X1_ROA &, 176 &, 136 &, 110 & 1,292 &, &, 864 & 1,158 \\
\cline { 2 - 9 } & X2_SIZE &, 042 &, 005 &, 847 & 7,816 &, &, 528 & 1,893 \\
\cline { 2 - 8 } & X3_DER &, 000 &, 005 &, 009 &, 092 &, &, 717 & 1,394 \\
\cline { 2 - 8 } & X4_UDPS &,- &, 012 &,- 396 & $-4,452$ &, &, 786 & 1,273 \\
\hline
\end{tabular}

a. Dependent Variable: Y_CSR

\section{c) Autocorrelation Test}

According to [4], autocorrelation test aims knowing the linear regression model, there is a correlation between confounding error in period $t$ with confounding error in period $t-1$ (previous).

\begin{tabular}{|c|c|c|c|c|c|}
\hline \multicolumn{6}{|c|}{ Model Summary } \\
\hline Model & $\mathrm{R}$ & R Square & $\begin{array}{ll}\text { Adjusted } & \mathrm{R} \\
\text { Square } & \end{array}$ & $\begin{array}{l}\text { Std. An error of the } \\
\text { Estimate }\end{array}$ & $\begin{array}{l}\text { Durbin- } \\
\text { Watson }\end{array}$ \\
\hline 1 & $833^{\mathrm{a}}$ & 693 & 670 & 03281 & 1,069 \\
\hline
\end{tabular}

a. Predictors: (Constant), X4_UDPS, X1_ROA, X3_DER, X2_SIZE

b. Dependent Variable: Y_C SR

\section{d) Heteroscedasticity Test}

The Glejser method test conducting a regression analysis of the independent variables on the absolute residual value. With the Glejser test, if the significance level is above 5\%, heteroscedasticity does not occur. However, if the significance level is below $5 \%$, there is heteroscedasticity [19].

\begin{tabular}{|l|l|l|l|l|l|l|}
\hline \multicolumn{2}{|l|}{ Coefficients * } & \multicolumn{2}{l|}{ Unstandardized Coefficients } & $\begin{array}{l}\text { Standardized } \\
\text { Coefficients }\end{array}$ & $\mathrm{t}$ & \multirow{2}{*}{ Sig. } \\
\cline { 2 - 7 } \multicolumn{2}{|l|}{ Model } & B & Std. Error & Beta & & \\
\hline \multirow{2}{*}{1} & (Constant) &, 112 &, 070 & & 1,592 &, 117 \\
\cline { 2 - 7 } & X1 ROA &, 040 &, 062 &, 093 &, 649 &, 519 \\
\cline { 2 - 7 } & X2_SIZE &,- 003 &, 003 &,- 201 & $-1,116$ &, 269 \\
\cline { 2 - 7 } & X3 DER &,- 002 &, 002 &,- 112 &,- 715 &, 478 \\
\cline { 2 - 7 } & X4 UDPS &, 001 &, 005 &, 024 &, 162 &, 872 \\
\hline
\end{tabular}

a. Dependent Variable: Abs_Res

The significance value of the profitability variable is 0.519 , the the size of company is 0.269 , the leverage is 0.478 , and the DPS is 0.872 . Each variable has a significance value $>$ 0.05 , so it can be concluded that there are no symptoms of heteroscedasticity in the regression model. 


\section{e) Model Fit Test}

1. The coefficient Determinansi $\left(\mathrm{R}^{2}\right)$

\begin{tabular}{|l|l|l|l|l|}
\hline \multicolumn{4}{|c|}{ Model Summary } \\
\hline Model & $\mathrm{R}$ & R Square & Adjusted R Square & $\begin{array}{l}\text { Std. An error of the } \\
\text { Estimate }\end{array}$ \\
\hline 1 &, &, 693 &, 670 &, 03281 \\
\hline
\end{tabular}

a. Predictors: (Constant), X4_UDPS, X1_ROA, X3_DER, X2_SIZE

The adjusted $\mathrm{R}$ Square value is 0.670 or $67.0 \%$. This shows the independent variable profitability (X1), company size (X2), leverage (X3), and DPS (X4) explain the CSR variance of $67.0 \%$ and the remaining $33,0 \%$ explained by other variables outside the regression model of this study.

b) $\mathrm{F}$ test

\begin{tabular}{|l|l|l|l|l|l|l|}
\hline \multicolumn{2}{|l|}{ ANOVA } \\
\hline \multicolumn{2}{|l|}{ Model } & $\begin{array}{l}\text { Sum of } \\
\text { Squares }\end{array}$ & df & Mean Square & F & Sig. \\
\hline \multirow{2}{*}{1} & Regression &, 129 & 4 &, 032 & 29,947 &, $000^{\circ}$ \\
\cline { 2 - 7 } & Residual &, 057 & 53 &, 001 & & \\
\cline { 2 - 7 } & Total &, 186 & 57 & & & \\
\hline
\end{tabular}

a. Dependent Variable: Y_C SR

b. Predictors: (Constant), X4_UDPS, X1_ROA, X3_DER, X2_SIZE

The regression model above shows that the $F$ value is 29.947 with a significant value of 0.000 less than 0.05 , the degree of freedom is obtained; $\alpha,(\mathrm{k}-1),(\mathrm{nk})$ or $0.05(4-1)(63-4)$ obtained $\mathrm{F}$ table at the $95 \%$ confidence level is 2.78 thus $\mathrm{F}_{\text {count }}>\mathrm{F}_{\text {table }}(29.947>2,76)$. From the results of this $\mathrm{F}$ test, it can be concluded that the regression equation model is fit (accepted).

c) Partial test (t-test)

\begin{tabular}{|l|l|l|l|l|l|l|}
\hline \multicolumn{2}{|l|}{ Coefficients a } \\
\hline \multicolumn{2}{|l|}{ Model } & \multicolumn{2}{l|}{$\begin{array}{l}\text { Unstandardized } \\
\text { Coefficients }\end{array}$} & $\begin{array}{l}\text { Standardized } \\
\text { Coefficients }\end{array}$ & $\mathrm{t}$ & Sig. \\
\cline { 3 - 7 } \multicolumn{2}{|l}{} & $\mathrm{B}$ & Std. Error & Beta & & \\
\hline \multirow{3}{*}{1} & (Constant) & 7,990 & 10,995 & &, 727 &, 470 \\
\cline { 2 - 7 } & ROA &,- 067 &, 100 &,- 072 &,- 673 &, 503 \\
\cline { 2 - 7 } & SIZE & 2,410 &, 401 &, 833 & 6,010 &, 000 \\
\cline { 2 - 7 } & DER &,- 794 &, 400 &,- 237 & $-1,984$ &, 052 \\
\cline { 2 - 7 } & UDPS & $-1,095$ &, 845 &,- 146 & $-1,296$ &, 200 \\
\hline
\end{tabular}

a. Dependent Variable: CSR

From Table 4 above, the value of $t$ profitability amounted to -0.673 , the size of the 
company's 6,010, leverage amounted to -1.984 and DPS -1.296 sample number 58 then Display the degrees of freedom $\mathrm{df}=58$ of k-1 with the level of significance of $95 \%$ or alpha $5 \%$ so that the $\mathrm{t}$ table value is 1.67155 .

\section{Influence of Profitability on CSR}

Direved from the results of the first hypothesis test partially obtained the results that profitability has a negative and insignificant influence on CSR disclosure. The test results show that the resulting significance value is 0.503 . This means that giving a p-value $<0.05$ is unacceptable. Results $0.503>0.05$ so that $\mathrm{Ha}$ is rejected, which means that profitability does not influence CSR disclosure. The amount of profit generated by the company does not influence the CSR disclosure made. Because CSR reporting must be done as a form of corporate responsibility to stakeholders [9], this research is in line with the research findings of Alfiyah (2018), Trisnawati (2014), [8], Lambey, et al. and [10] showing that profitability does not have a significant influence on CSR disclosure. This means that in carrying out CSR disclosures, you must pay attention to the company's size in obtaining a profit.

\section{The Influence of The size of company on CSR}

The second hypothesis test results partially obtained the results that the size of company has a significant positive influence on CSR disclosure. The test results show the resulting significant value of 0,000 . This means that the p-value $<0.05$ is acceptable. Results of $0,000<$ 0,05 , that means the size of the company influence significant positive to the disclosure of CSR. This shows that the total assets owned will influence CSR disclosure. The bigger the the size of company or, the higher the total assets, the greater the CSR disclosure. Generally, large companies will disclose more information about small company CSR because large companies attract people's attention and face political risks and the pressure to do more CSR than small companies. More and more CSR disclosure is an effort to reduce administrative costs. This research is in line with the research findings of Rahman (2013), [25], Masrurroh (2017), Yadnya, and Purba (2015) and [10] showing that the size of company has a significant positive influence on CSR disclosure.

\section{Influence of Leverage on CSR}

Based on the results of the third hypothesis test partially, the results show that leverage has a negative and insignificant influence on CSR disclosure at $\mathrm{p}$-value $5 \%$ but significant at $\mathrm{p}$ value $10 \%$. The test results show that the resulting significance value is $0.052<0.1$ so that $\mathrm{H}$ a is rejected, which means that leverage has a negative influence on CSR disclosure. The application of leverage cannot add value to the company due to tax calculations, which occurs due to the use of debt being suppressed, thus causing the company to experience tax difficulties. If the debt is high, the company will find it difficult to allocate funds for CSR so that CSR disclosure will be lower. This research is in line with the research findings of Purba \& Yadna (2015) and Alfiyah (2018) but not in line with the research of [6], [25], Swandari and Sodikin (2016), and [10] which state that leverage does not influence. Significant towards CSR disclosure.

\section{The influence of DPS on CSR}

Based on the results of the fourth hypothesis test partially, the results show that DPS has a negative and insignificant influence on CSR disclosure. The test results show that the resulting significant value is 0.200 . This means that giving a p-value $<0.05$ is unacceptable. The result 
is $0.200>0.05$, so Ha is rejected, which means that DPS does not influence CSR disclosure. The results of this test provide an interpretation that the increasing number of sharia supervisory boards will not increase the disclosure of social responsibility because the ability of the number of sharia supervisory board members to carry out their duties and functions, namely controlling and monitoring the activities of Islamic commercial banks (BUS) based on sharia principles is far more productive and influenceive. Efficient. This study's results are in line with and support the results of research conducted by [6].

\section{Conclusion and Suggestion}

The research findings show that Return On Asset and Sharia Advisory Board does not influence Corporate Social Responsibility Disclosure. This indicates that the Sharia Advisory Board is not capable of promoting CSR in the company. Meanwhile, The size of company has a positive influence on CSR Disclosure. It means Big companies always pay attention to CSR. Leverage has a negative influence on CSR Disclosure. The implication of this research is the Islamic Commercial Bank have both increases the total asset and decrease leverage

The results of the research with a low R-square value indicate that the independent variable cannot affect the dependent variable as a whole, meaning that there are other factors that have not been studied. Other factors that influence CSR disclosure have not been included in this research model. Inputs for further research are the addition of the observation unit, the expansion of the sample and the addition of the research observation period.

\section{References}

[1] ojk.go.id 2018 pada tanggal 12 September 2018 pada jam 14:15.

[2] Indonesia Sharia Financial Development Report, 2018

[3] Islamic Finance Development Report, 2017

[4] Santoso et al.: Pengaruh Kepemilikan Saham Publik, Ukuran Perusahaan dan Profitabilitas Terhadap Corporate Social Responsibility Disclosure (Studi Pada Perusahaan Perbankan Yang Terdaftar Di Bei Periode 2012-2015. Vol. 5 No. 1. Forum Ilmiah Pendidikan Akuntansi - Universitas PGRI Madiun (2017)

[5] Nurfrianto \& Hanny.: Pengaruh Ukuran Perusahaan, Likuiditas, Leverage dan Profitabilitas Perusahaan Terhadap Corporate Social Responsibility Disclosure (Studi Empiris Pada Perusahaan Manufaktur Sektor Industri Dasar dan Kimia Yang Terdaftar Di Bursa Efek Indonesia Tahun 2013-2017) ( 2016)

[6] Rahayu and Cahyati.: Faktor-Faktor Yang Mempengaruhi Pengungkapan Corporate Social Responsibility (CSR) pada Perbankan Syariah. Jurnal Riset Akuntansi Komtemporer. Vol.5 No.2.Pp.38-51 (2014)

[7] Mardikanto.: Corporate Social Responcibility (CSR) Tanggung Jawab Sosial Korporasi”. Bandung: Alfabeta. Cetakan Kedua (2018)

[8] Sitorus dan Harahap.: Pengungkapan Corporate Social Responsibility: Berdasarkan Tingkat Profitabilitas, Leverage, dan Ukuran Perusahaan. ISSN- 2252-3936. Profesionalisme Akuntan Menuju Sustainable Business Practice (2017)

[9] Ribut dan Ari.: Faktor-Faktor yang Mempengaruhi Pengungkapan Corporate Social Responsibility (CSR) Pada Perbankan Syariah. JRAK Vol. 5 No. 2. (2014)

[10] Riantani dan Nurzamzam.: Analisis Ukuran Perusahaan, Leverage, dan Profitabilitas terhadap Pengungkapan CSR. Vol. 6, No. 2, pp: 203-213. Jurnal Dinamika Manajemen (2015) 
[11] Trinanda.: Analisis Pengaruh Size, Profitabilitas Dan Leverage Terhadap Corporate Social Responsibility Disclosure (Studi Empiris Pada Perusahaan Jasa Sektor Property Dan Real Estate Yang Terdaftar Di Bursa Efek Indonesia Tahun 2016). Vol.1, No 1. Progress Conference (2017)

[12] Nurhasanah.: Pengaruh Struktur Kepemilikan, Kinerja Keuangan dan Size Perusahaan Terhadap Corporate Social Responsibility Disclosure (Csrd) Pada Perusahaan Nonkeuangan yang Terdaftar di Daftar Efek Syariah Indonesia. Vol. 1 No. 2. Value Journal Of Management And Business (2017)

[13] Sumilat dan Destriana.: Faktor-Faktor Yang Empengaruhi Pengungkapan Corporate Social Responsibility. Vol. 19, No. 1a. Jurnal Bisnis Dan Akuntansi (2017)

[14] Rena, dkk.: Pengaruh Komisaris Independen, Dewan Pengawas Syariah, Kepemilikan Institusional, dan Profitabilitas Terhadap Tingkat Pengungkapan Tanggung-jawab Sosial pada Bank Syariah di Indonesia. Jurnal Riset Akuntansi dan Auditing (2017)

[15] Qoyum, dkk.: The Impact of Good Corporate Governance, Company Size nn Corporate Social Responsibility Disclosure “Case Study of Islamic Banking in Indonesia”. Volume 10 No 1 (2017)

[16] Umi dan Baiquni.: Ukuran Perusahaan, Profitabilitas, dan Leverage Terhadap Islamic Social Reporting Pada Bank Umum Syariah Di Indonesia. Volume 6(1). Jurnal Akuntansi Dan Keuangan Islam (2018)

[17] Arjanggie.: Pengaruh Profitabilitas dan Umur Perusahaan Terhadap Pengungkapan Tanggung Jawab Sosial Perusahaan (Studi Empiris Pada Perusahaan Industri Dasar dan Kimia yang terdaftar di Bursa Efek Indonesia). Semarang, Universitas Diponegoro (2015)

[18] Syamsuddin. : Manajemen Keuangan Perusahaan: Konsep Aplikasi dalam: Perencanaan, Pengawasan, dan Pengambilan Keputusan.Rajawali Pers. Jakarta (2009)

[19] Ghozali, Imam.: Aplikasi Analisis Multivariete dengan program IBM SPSS 21. Edisi 8. Semarang: BP Universitas di Ponegoro (2016)

[20] Sujarweni, Wiratna.: Metedologi Penelitian Bisnis \& Ekonomi. Yogyakarta: Pustaka Baru Pres (2015)

[21] Hanafi, \& Halim.: Analisis Laporan Keuangan. Yogyakarta: Penerbit : UPP STIM YKPN (2016).

[22] Syafri.: Analisis Kritis Atas Laporan Keuangan, Rajagrafindo Persada, Jakarta (2016)

[23] Sugiyono.: Metode penelitian kuantitatif, kualitatif, dan R\&D. Bandung: Alfabeta (2018)

[24] Santoso, Singgih.: Panduan Lengkap SPSS Versi 20. Jakarta: PT Elex Media Komputindo (2014)

[25] Trisnawati, R.: Pengaruh Ukuran Perusahaan, Profitabilitas, Leverage, Ukuran Dewan Komisaris Dan Kepemilikan Manajerial Terhadap Pengungkapan Corporate Social Responsibility (CSR) Industri Perbankan di Indonesia (2014) 